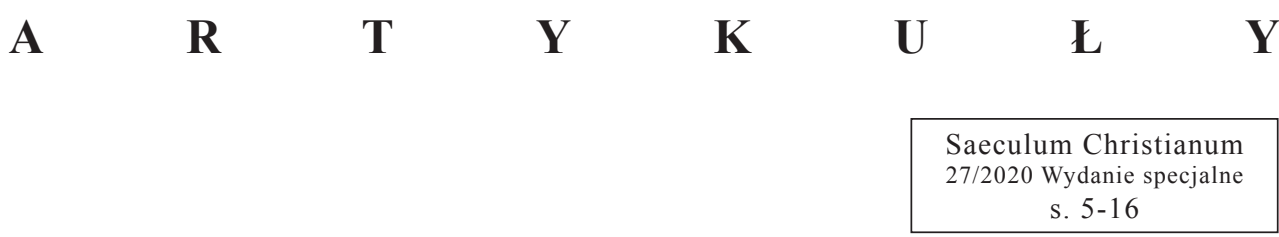

\author{
AGNIESZKA NALEWAJEK* \\ Wydział Nauk Historycznych \\ Uniwersytet Kardynała Stefana Wyszyńskiego, Warszawa \\ ORCID: 0000-0001-5155-4511
}

\title{
MIĘDZY DWOREM KRÓLEWSKIM A SENATEM. NOMINACJE OSÓB Z KRĘGÓW DWORSKICH NA GODNOŚCI SENACKIE ZA PANOWANIA KRÓLA JANA OLBRACHTA
}

\section{Between the royal court and the Senate. Nominations of people from court circles for the Senate during the reign of King Jan Olbracht}

\section{Abstract}

After the death of king Kazimierz Jagiellończyk (d. 1492), in whose reign the bicameral General Crown Sejm was formed, consisting of the Senate and the Chamber of Deputies, filling vacancies in the Senate was a key criterion for the appointment of episcopal positions and the highest offices used by his successor, Jan Olbracht (1492-1501). He used a personnel policy to influence the Senate by filling the upper house with his closest royal associates. Senatorial vacancies were filled mainly by court members associated with the Crown office, royal officials and secretaries. The royal court was a school shaping future Senators of the Republic of Poland.

Keywords: King Jan Olbracht, Sejm, Senate, royal court, senatorial vacancies

\begin{abstract}
Abstrakt
Po śmierci króla Kazimierza Jagiellończyka (zm. 1492), za panowania którego doszło do ukształtowania dwuizbowego sejmu walnego koronnego składającego się z senatu i izby poselskiej, obsada godności senackich stanowiła kluczowe kryterium przy nominacjach na godności biskupie oraz najwyższe urzędy stosowane przez jego następcę, Jana Olbrachta (1492-1501). Wykorzystywał on politykę personalną do wywierania wpływu na kształt senatu poprzez obsadzenie izby wyższej najbliższymi współpracownikami królewskimi. Godności senackie otrzymywali głównie członkowie dworu związani z kancelarią koronną, \footnotetext{
szawie. Prowadzi badania nad kulturą i społeczeństwem staropolskim, polskim dworem królewskim, rodami szlacheckimi. Email: a.nalewajek@uksw.edu.pl.
}

* Dr Agnieszka Nalewajek - adiunkt w Katedrze Historii Nowożytnej w Instytucie Historii WNH UKSW w War-
\end{abstract}


urzędnicy i sekretarze królewscy. Dwór monarszy był szkołą kształtującą przyszłych senatorów Rzeczypospolitej.

Słowa kluczowe: król Jan Olbracht, sejm, senat, dwór królewski, godności senackie

Za datę najstarszego sejmu walnego koronnego dwuizbowego uważa się rok 1468, w którym doszło do sejmu generalnego w Piotrkowie z udziałem króla, rady królewskiej, czyli senatorów oraz posłów ziemskich będących przedstawicielami szlachty. Skład sejmu z podziałem na dwie izby, senat i izbę poselską, ustalił się podczas sejmów walnych zwoływanych w następnych latach, przed rokiem 1493, który do niedawna był przyjmowany za datę powstania sejmu dwuizbowego ${ }^{1}$. Funkcję senatu pełniła wówczas rada królewska składająca się z członków episkopatu rzymskokatolickiego, wojewodów i kasztelanów większych oraz ministrów, którymi byli centralni urzędnicy koronni². Skład osobowy izby senatorskiej odzwierciedlały listy świadków dokumentów wystawianych na sejmach ${ }^{3}$.

Podczas panowania następcy Kazimierza Jagiellończyka w 1492 r. miał miejsce sejm koronacyjny w Krakowie, a następnie doszło do pięciu sejmów walnych, z których cztery odbyły się w Piotrkowie w 1493, 1496, 1498 i 1501 r. oraz jeden w Krakowie w 1499 r. ${ }^{4}$ Zaplanowany był też sejm w Radomiu w 1494 r., w ramach którego doszło jedynie do zjazdu senatu ${ }^{5}$. Listy senatorów, którzy uczestniczyli w obradach sejmów zwołanych przez Jana Olbrachta ukazuje poniższa tabela.

Tab. 1. Senatorowie obecni na sejmach w latach panowania Jana Olbrachta (1492-1501)

\begin{tabular}{|c|c|c|}
\hline Sejmy & Senatorowie & Liczba \\
\hline $\begin{array}{l}\text { Sejm korona- } \\
\text { cyjny w Krako- } \\
\text { wie w } 1492 \text { r. }^{a}\end{array}$ & $\begin{array}{l}\text { Kardynał Fryderyk Jagiellończyk elekt krakowski, arcybiskup gnieźnieński Zbigniew } \\
\text { Oleśnicki, biskupi: włocławski Piotr Mosiński, poznański Uriel Górka, chełmski } \\
\text { Maciej ze Starej Łomży, kasztelan krakowski Jan Amor Tarnowski; wojewodowie: } \\
\text { krakowski Spytek Jarosławski, kaliski Jan Świdwa Szamotulski, sieradzki Mikołaj } \\
\text { Brudzewski, brzeski Jan Oporowski, inowrocławski Maciej Służewski, ruski Jan } \\
\text { z Pilczy, lubelski Dobiesław Kurozwęcki, sandomierski Rafał Jarosławski marsza- } \\
\text { łek Królestwa Polskiego; kasztelanowie: poznański Jan z Ostroroga, gnieźnieński } \\
\text { Sędziwój z Czarnkowa, wojnicki Andrzej Tęczyński, przemyski Stanisław Kmita; } \\
\text { ministrowie nie sprawujący innych godności senackich: kanclerz Królestwa Polskiego } \\
\text { Krzesław Kurozwęcki, podskarbi Królestwa Polskiego Piotr Kurozwęcki, podkancle- } \\
\text { rzy Królestwa Polskiego Grzegorz Lubrański }\end{array}$ & 21 \\
\hline
\end{tabular}

\footnotetext{
1 W. Uruszczak, Najstarszy sejm walny koronny , dwuizbowy” w Piotrkowie w 1468 roku, w: Narodziny Rzeczypospolitej: studia z dziejów średniowiecza i czasów wczesnonowożytnych, red. W. Bukowski, T. Jurek, t. 2, Kraków 2012, s. 1033-1056.

2 S. Kutrzeba, Skład Sejmu Polskiego 1493-1793, „Przegląd Historyczny”, 2/1906, z. 1, s. 46-50; J. Brzozowski, Zygmunt I a senat koronny w latach 1506-1535, „Białostockie Teki Historyczne”, 9/2011, s. 11.

3 S. Kutrzeba, Skład Sejmu, dz. cyt., s. 46; W. Uruszczak, Sejm koronacyjny w 1507 roku w Krakowie, „Studia z Dziejów Państwa i Prawa Polskiego", 7/2002, s. 113, 120-121.

4 Volumina Constititionum (dalej: VC), t. 1: 1493-1526, oprac. S. Grodziski, I. Dwornicka, W. Uruszczak, Warszawa 1996, s. 45-99; F. Papée, Jan Olbracht, Kraków 2006 (wyd. 1, 1936), s. 37.

5 F. Papée, Jan Olbracht, dz. cyt., s. 72. Zapisy znajdujące się w jednej z ksiąg rachunkowych wskazują, że na początku kwietnia 1500 r. z udziałem króla odbył się również zjazd w Nowym Mieście Korczynie, o którym nie ma dokładniejszych informacji. AGAD, Archiwum Skarbu Koronnego, Oddział 86, Rachunki z przychodów i wydatków na potrzeby wojska, sygn. 4, k. 127v, 128v (dalej: Rw).
} 


\begin{tabular}{|c|c|c|}
\hline Sejmy & Senatorowie & Liczba \\
\hline $\begin{array}{l}\text { Sejm walny } \\
\text { w Piotrkowie } \\
\text { w } 1493 \text { r. }\end{array}$ & $\begin{array}{l}\text { Kardynał Fryderyk Jagiellończyk biskup krakowski, biskupi: włocławski Piotr } \\
\text { Mosiński, poznański Uriel Górka, arcybiskup teomoński Andrzej Róża Borzyszowski } \\
\text { koadiutor lwowski, chełmski Maciej ze Starej Łomży, kasztelan krakowski Jan Amor } \\
\text { Tarnowski, wojewodowie: krakowski Spytek Jarosławski, kaliski Jan Świdwa Szamo- } \\
\text { tulski, brzeski Jan Oporowski, inowrocławski Maciej Służewski, ruski Jan z Pilczy, } \\
\text { lubelski Dobiesław Kurozwęcki, rawski Andrzej z Kozłowa; kasztelanowie: poznański } \\
\text { Jan z Ostroroga, kaliski Andrzej Szamotulski, gnieźnieński Sędziwój z Czarnkowa, } \\
\text { sieradzki Mikołaj Kurozwęcki, wojnicki Andrzej Tęczyński, rozpierski Ambroży Pam- } \\
\text { powski, żarnowiecki Jan Podlodowski; ministrowie nie sprawujący innych godności } \\
\text { senackich: kanclerz Królestwa Polskiego Krzesław Kurozwęcki, podskarbi Królestwa } \\
\text { Polskiego Piotr Kurozwęcki, podkanclerzy Królestwa Polskiego Grzegorz Lubrański, } \\
\text { marszałek nadworny Rafał Leszczyński }\end{array}$ & 24 \\
\hline $\begin{array}{l}\text { Sejm walny } \\
\text { w Piotrkowie } \\
\text { w } 1496 \text { r. }^{\mathrm{c}}\end{array}$ & $\begin{array}{l}\text { Arcybiskupi: gnieźnieński kardynał Fryderyk Jagiellończyk, lwowski Andrzej Róża } \\
\text { Borzyszowski; biskupi: poznański Uriel Górka, włocławski Krzesław Kurozwęcki } \\
\text { kanclerz Królestwa Polskiego, przemyski Mikołaj Prymus, płocki Piotr z Chotkowa; } \\
\text { krakowski Spytek Jarosławski; wojewodowie: poznański Jan Świdwa Szamotul- } \\
\text { ski, kaliski Andrzej Szamotulski, sieradzki Ambroży Pampowski, brzeski Mikołaj } \\
\text { Służewski, ruski Jan z Pilczy, lubelski Mikołaj z Ostrowa, bełski Mikołaj Tęczyński; } \\
\text { kasztelanowie: poznański Jan z Ostroroga, sandomierski Piotr Kurozwęcki podskarbi } \\
\text { Królestwa Polskiego, gnieźnieński Rafał Leszczyński marszałek nadworny, wojnicki } \\
\text { Andrzej Tęczyński, wiślicki Mikołaj Strzeżowski, rozpierski Piotr Myszkowski, } \\
\text { międzyrzecki Dobrogost z Ostroroga, lwowski Stanisław Chodecki, lądzki Miko- } \\
\text { łaj Gardzina Lubrański, przemyski Stanisław Kmita, brzeski Andrzej z Lubienia, } \\
\text { gostyniński Andrzej z Kutna, małogoski Jan Oleski, żarnowiecki Jakub Drzewicki, } \\
\text { połaniecki Marcin z Wrocimowic, spycimierski Jan Jarand Brudzewski, kruszwicki } \\
\text { Mikołaj Kościelecki, rypieński Mikołaj Kretkowski, płocki Mikołaj Dobrzykowski, } \\
\text { wiski Ninogniew Kryski, raciąski Zawisza Dłużniewski; ministrowie nie sprawujący } \\
\text { innych godności senackich: marszałek Królestwa Polskiego Piotr Kmita }\end{array}$ & 36 \\
\hline $\begin{array}{l}\text { Sejm walny } \\
\text { w Piotrkowie } \\
\text { w } 1498 \text { r. }\end{array}$ & $\begin{array}{l}\text { Arcybiskup gnieźnieński kardynał Fryderyk Jagiellończyk; biskupi: włocławski } \\
\text { Krzesław Kurozwęcki kanclerz Królestwa Polskiego, elekt płocki Jan Lubrański; kasz- } \\
\text { telan krakowski Jan Amor Tarnowski; wojewodowie: krakowski Spytek Jarosławski, } \\
\text { sieradzki Ambroży Pampowski, łęczycki Maciej Służewski, lubelski Jan Tarnowski, } \\
\text { inowrocławski Jan Kościelecki, rawski Andrzej z Kutna; kasztelanowie: poznański } \\
\text { Jan z Ostroroga, sandomierski Piotr Kurozwęcki podskarbi Królestwa Polskiego, } \\
\text { sieradzki Mikołaj Kurozwęcki, Piotr Kmita marszałek Królestwa Polskiego, sądecki } \\
\text { Piotr Myszkowski }\end{array}$ & 15 \\
\hline $\begin{array}{l}\text { Sejm walny } \\
\text { w Krakowie } \\
\text { w } 1499 \text { r. }\end{array}$ & $\begin{array}{l}\text { Arcybiskupi: gnieźnieński Fryderyk, lwowski Andrzej Róża Borzyszowski, włocław- } \\
\text { ski Krzesław Kurozwęcki kanclerz Królestwa Polskiego, poznański Jan Lubrański, } \\
\text { płocki Wincenty Przerębski podkanclerzy Królestwa Polskiego, warmiński Łukasz } \\
\text { Watzenrode, chełmski Maciej ze Starej Łomży; kasztelan krakowski Jan Amor } \\
\text { Tarnowski, wojewodowie: krakowski Spytek Jarosławski, sandomierski Mikołaj } \\
\text { z Ostrowa, sieradzki Ambroży Pampowski, malborski Mikołaj Bażyński, ruski Jakub } \\
\text { z Buczacza, bełski Piotr Myszkowski starosta generalny Rusi; kasztelanowie; poznań- } \\
\text { ski Jan z Ostroroga, gnieźnieński Rafał Leszczyński, sieradzki Mikołaj Kurozwęcki, } \\
\text { wojnicki Andrzej Tęczyński, starosta krakowski i sądecki Mikołaj Kamieniecki, płocki } \\
\text { Zawisza Dłużniewski, przemyski Stanisław Kmita, lwowski Stanisław Chodecki, } \\
\text { śremski Stanisław Imbir, czechowski Piotr Gniady, połaniecki Mikołaj z Chodczy }\end{array}$ & 24 \\
\hline
\end{tabular}




\begin{tabular}{|l|l|c|}
\hline \multicolumn{1}{|c|}{ Sejmy } & \multicolumn{1}{|c|}{ Senatorowie } & Liczba \\
\hline Sejm walny & Arcybiskup gnieźnieński kardynał Fryderyk Jagiellończyk; biskupi: poznański Jan & 13 \\
w Piotrkowie & Lubrański, płocki Wincenty Przerębski; kasztelan krakowski Spytek Jarosławski, wo- \\
w 1501 r. & jewodowie: krakowski Piotr z Kmita marszałek Królestwa Polskiego, kaliski Andrzej \\
& $\begin{array}{l}\text { Szamotulski, sieradzki Ambroży Pampowski starosta generalny wielkopolski, brzeski } \\
\text { Mikołaj Kościelecki, lubelski Jan Tarnowski, bełski Piotr Myszkowski; kasztelanowie: } \\
\text { gnieźnieński Mikołaj Gardzina Lubrański, lwowski Stanisław Chodecki, lądzki Jan } \\
\text { Polak Karnkowski }\end{array}$ & \\
\hline
\end{tabular}

a Lista senatorów na podstawie dokumentu wystawionego podczas sejmu w Krakowie 1 października 1492 r.: AGAD, Metryka Koronna, sygn. MK 17, k. 5v.

b AGAD, Metryka Koronna, sygn. MK 17, k. 27v, 28v, 29, 29v.

VC, t. 1, s. 84-85.

d AGAD, Metryka Koronna, sygn. MK 16, k. 252, 153.

VC, t. 1, s. 92-93.

f AGAD, Metryka Koronna, sygn. MK 19, k. 9.

Prawo do zasiadania w radzie królewskiej tworzącej senat, na forum którego dygnitarze koronni rozstrzygali kwestie polityczne i ustrojowe, stanowiło kluczowe kryterium przy obsadzie godności biskupich oraz nominacjach na najwyższe urzędy stosowane przez Jana Olbrachta na wzór rządów Kazimierza Jagiellończyka. Senat miał silne zaplecze w dworze monarszym, który władca wykorzystywał do prowadzenia polityki personalnej. Doszło wtedy do kilku istotnych zmian w składzie izby wyższej, z których najważniejszą była kwestia pierwszego miejsca w senacie dla brata królewskiego kardynała Fryderyka Jagiellończyka (zm. 1503), z którą wiązało się obsadzenie go na arcybiskupstwie gnieźnieńskim w 1493 r. ${ }^{6}$

Pierwszeństwo najmłodszego syna Kazimierza Jagiellończyka na liście senatorów zostało zaznaczone podczas sejmu koronacyjnego w 1492 r. Godność kardynalska królewicza Fryderyka spowodowała przesunięcie w senacie pozycji arcybiskupa gnieźnieńskiego Zbigniewa Oleśnickiego (zm. 1493) na drugie miejsce, które nie odpowiadało posiadanemu przezeń tytułowi prymasowskiemu. Na następnym sejmie walnym w Piotrkowie w $1493 \mathrm{r}$. godność arcybiskupa gnieźnieńskiego wakowała po śmierci Zbigniewa Oleśnickiego, a brat królewski Fryderyk Jagiellończyk, wysuwany na czoło polskiej hierarchii kościelnej, został kandydatem popieranym przez Jana Olbrachta do objęcia uprzywilejowanego zwierzchnictwa nad katedrą gnieźnieńską ${ }^{7}$. Następnym w kolejności biskupem senatorem był wówczas przychylny następcy Kazimierza Jagiellończyka biskup włocławski Piotr Mosiński (zm. 1494). Warto zauważyć, że od niego pochodziła jedna z pierwszych wpłat po koronacji Jana Olbrachta przeznaczonych na bieżące wydatki królewskie, zanim władca otrzymał pieniądze od podskarbiego koronnego ${ }^{8}$. Po uzyskaniu godności prymasowskiej kardynał Fryderyk zajmował pierwsze miejsce podczas wszystkich kolejnych sejmów walnych, które odbyły się w następnych latach panowania następcy Kazimierza Jagiellończyka.

Druga pozycja w kolejności senatorów w tym okresie przypadła oddanemu dynastii jagiellońskiej, doświadczonemu dyplomacie Andrzejowi Róży Borzyszowskiemu (zm. 1510),

\footnotetext{
F. Papée, Jan Olbracht, dz. cyt., s. 53-54.

Tamże, s. 53.

8 AGAD, Archiwum Skarbu Koronnego, Oddział 1, Rachunki Królewskie, sygn. 20, s. 7 (dalej: Rk); Rk 338, k. $36 \mathrm{v}$.
} 
który w 1494 r. objął arcybiskupstwo lwowskie9. W skład izby wyższej wszedł podczas sejmu w Piotrkowie w 1493 r. jako tytularny arcybiskup teomoński oraz koadiutor lwowski, i zajął miejsce pośród hierarchów kościelnych po kardynale Fryderyku oraz biskupach: włocławskim Piotrze Mosińskim i poznańskim Urielu Górce (zm. 1498), byłym kanclerzu koronnym. Po konfirmacji na arcybiskupstwo lwowskie w 1494 r. Andrzej Róża Borzyszowski był uczestnikiem sejmów w Piotrkowie w 1496 r. oraz w Krakowie w 1499 r. Nie wziął on udziału w sejmach walnych w Piotrkowie w 1498 oraz w 1501 r. Arcybiskup Andrzej Borzyszowski przeżył zarówno Jana Olbrachta, jak i Fryderyka Jagiellończyka, po śmierci którego w 1503 r. osiągnął arcybiskupstwo gnieźnieńskie i tytuł prymasowski.

Wysoki awans w gronie senatorów za panowania Jana Olbrachta osiągnął kanclerz Krzesław Kurozwęcki (zm. 1503) ${ }^{10}$. Na sejmach w roku 1492 i 1493 był wymieniany na odległej pozycji po biskupach, wojewodach oraz kasztelanach, pośród urzędników koronnych nieposiadających innych godności senackich. Kanclerz brał w nich udział w roli kierownika kancelarii królewskiej oraz dostojnika dworu monarszego i bliskiego współpracownika władcy. Na zjeździe w Radomiu we wrześniu 1494 r. Krzesław Kurozwęcki jako elekt włocławski otrzymał miejsce za biskupem poznańskim Urielem Górką, który po śmierci Piotra Mosińskiego przesunął się na trzecią pozycję w senacie ${ }^{11}$. Na tym miejscu występował podczas sejmu w 1496 r. Dwa i trzy lata później, po zmianie na biskupstwie poznańskim, Krzesław Kurozwęcki był wymieniany przed Janem Lubrańskim (zm. 1520), który otrzymał tamtejszą diecezję. Biskup włocławski z powodu sprawy oskarżenia jego brata podskarbiego koronnego Piotra Kurozwęckiego o psucie monety był nieobecny na sejmie w 1501 r., a następnie wrócił do sprawowania obowiązków kanclerza po śmierci króla Jana Olbrachta ${ }^{12}$.

$\mathrm{Na}$ listach odzwierciedlających skład izby wyższej podczas kolejnych sejmów walnych w następnych latach panowania Jana Olbrachta znaleźli się trzej biskupi-senatorowie należący do grona najbliższych współpracowników następcy Kazimierza Jagiellończyka. W senacie jako biskup przemyski zasiadł Mikołaj Krajewski zwany Prymusem (zm. 1498), który przed 1492 r. pełnił funkcję kanclerza królewicza Jana Olbrachta. Pojawił się on na zjeździe w Radomiu w 1494 r., a także wziął udział w sejmie piotrkowskim w 1496 r. ${ }^{13}$

Pozycję pośród senatorów od czasu wielkiego sejmu w Piotrkowie w 1496 r., po przyłączeniu Płocka do Korony, zajęli biskupi płoccy. Następcą Pawła z Chotkowa (zm. 1497) w diecezji płockiej w 1497 r. został doktor Jan Lubrański, który był sekretarzem królewskim ${ }^{14}$. Figurował on jako elekt płocki na liście senatorów obecnych na sejmie w 1498 r. Rok później Jan Lubrański został przeniesiony na biskupstwo poznańskie, a biskupem płockim został

\footnotetext{
9 B. Nowak, Ród Porajów w Małopolsce w średniowieczu, Kraków 2009, s. 400-402; F. Papée, Boryszewski Andrzej Róża, w: Polski Słownik Biograficzny (dalej: PSB), t. 2, Kraków 1936, s. 359-360.

10 Urzędnicy centralni i nadworni Polski XIV-XVIII wieku. Spisy, oprac. K. Chłapowski i in., red. A. Gąsiorowski, Kórnik 1992, nr 202 (dalej: UrzCentr); B. Nowak, Ród Porajów, dz. cyt., s. 165-268; F. Papée, Jan Olbracht, dz. cyt., s. 21 i n.

11 AGAD, Metryka Koronna, sygn. MK 15, k. 86v.

12 W. Kujawski, Krzesław z Kurozwęk, wielki kanclerz koronny i biskup włocławski, „Studia Włocławskie”, 7/2004, s. 340-354.

13 A. Strzelecka, Krajewski (Krajowski) Mikołaj, zwany Primus (zm. 1498), w: PSB, t. 15, Wrocław-Warszawa-Kraków 1970, s. 113-114.

14 L. Hajdukiewicz, Lubrański Jan, w: PSB, t. 18, Wrocław-Warszawa-Kraków-Gdańsk 1973, s. 81-84.
} 
podkanclerzy Wincenty Przerębski (zm. 1513) ${ }^{15}$. Na sejmie w Krakowie w 1499 r. zajmowali oni pozycje po prymasie Fryderyku Jagiellończyku, arcybiskupie Andrzeju Borzyszowskim oraz biskupie Krzesławie Kurozwęckim. Z kolei na ostatnim sejmie, który odbył się za panowania Jana Olbrachta, byli oni obok brata królewskiego Fryderyka jedynymi obecnymi biskupami-senatorami.

Nominacje biskupie dla Jana Lubrańskiego oraz Wincentego Przerębskiego wpisywały się w istniejącą od czasów pierwszych Jagiellonów praktykę powoływania na diecezje sekretarzy królewskich. W hierarchii dworu królewskiego w drugiej połowie XV wieku osoby posiadające rangę sekretarzy zajmowały najwyższy stopień po dostojnikach piastujących urzędy. Sekretarze mieli kompetencje do wykonywania zadań leżących w gestii urzędników królewskich oraz prowadzenia spraw, często o najwyższej wadze państwowej. Za panowania Jana Olbrachta rangę tę miały nieliczne osoby, w tym będący wcześniej sekretarzami królewskimi Kazimierza Jagiellończyka, Mikołaj Kościelecki i Wincenty Przerębski, a także dwaj bratankowie podkanclerzego Grzegorza z Lubrańca, Bernard i Jan Lubrańscy. Podobnie jak urzędnicy królewscy, sekretarze należący do stanu duchownego posiadali poczty konne ${ }^{16}$.

Spośród wymienionych, pierwszy na biskupstwo awansował doktor praw obojga Jan Lubrański, którego postrzegano na dworze królewskim Jana Olbrachta jako znakomitego prawnika i intelektualistę. Jego działalność sekretarska skupiała się na najważniejszych kwestiach z zakresu polityki prowadzonej przez władcę ${ }^{17}$. W 1497 r. Jan Lubrański był jednym z pretendentów do objęcia podkanclerstwa po rezygnacji z urzędu Grzegorza Lubrańskiego. W wyniku polityki nominacyjnej Jana Olbrachta został on skierowany na biskupstwo płockie, a tytuł podkanclerzego otrzymał Wincenty Przerębski, który posiadał szerokie doświadczenie z zakresu wykonywania kompetencji administracyjnych, a także wynikające z pełnienia przez niego obowiązków sekretarza wielkiego ${ }^{18}$. Od początku panowania następcy Kazimierza Jagiellończyka nazwisko Przerębskiego pojawiało się także w kontekście udzielania pożyczek na bieżące wydatki nadworne ${ }^{19}$. Po nominacji na biskupstwo płockie w 1498 r. łączył on do maja następnego roku sprawowanie urzędu podkanclerskiego z godnością biskupią. Nazwisko Wincentego Przerębskiego, podobnie jak wcześniej podkanclerzego Grzegorza Lubrańskiego, figurowało na listach wypłat dla członków dworu pobierających wynagrodzenie za poczty konne. Po uzyskaniu podkanclerstwa posiadał on poczet 20-konny, następnie w 1499 r. pobierał na dworze królewskim uposażenie za poczet 24-konny ${ }^{20}$. W 1503 r. został on następcą kanclerza Krzesława Kurozwęckiego na biskupstwie włocławskim i zajął jego pozycję w senacie.

W okresie panowania Jana Olbrachta doszło do kilku zmian w obsadzie urzędów wojewodów, które były widoczne podczas odbywających się wówczas sejmów walnych. Z kręgów dworskich związanych z następcą Kazimierza Jagiellończyka pierwszą osobą, która awansowała do tego grona, był dawny krajczy królewiczów, chorąży oraz krajczy nadworny

15 UrzCentr, nr 631; K. Baczkowski, Przerębski Wincenty, w: PSB, t. 29, Wrocław-Warszawa-Kraków-Gdańsk-Łódź 1986, s. 4-7.

16 Rw 2, k. 10, 24, 64, 66.

17 F. Papeé, Jan Olbracht, dz. cyt., s. 57, 60, 93, 110, 117.

18 W. Chorążyczewski, Przemiany organizacyjne polskiej kancelarii królewskiej u progu czasów nowożytnych, Toruń 2007, s. 141-143; F. Papeé, Jan Olbracht, dz. cyt., s. 117.

19 Rk 20, s. 24, k. 21v, 28; Rk 22, k. 71; Rk 338, k. 36v, 37v.

20 Rw 2, k. 11, 66; Rk 338, k. 35v. 
Ambroży Pampowski (zm. 1510) ${ }^{21}$. Po nieobecności w Krakowie na sejmie koronacyjnym w 1492 r. został on ściągnięty na sejm walny do Piotrkowa w 1493 r., zajął miejsce pośród kasztelanów. W otoczeniu dworskim następcy Kazimierza Jagiellończyka Pampowski pojawił się w czerwcu $1493 \mathrm{r}$. z dawnym tytułem krajczego nadwornego i towarzyszył władcy w następnych latach jego rządów ${ }^{22}$. W 1494 r. został nominowany na wojewodę sieradzkiego, a następnie w 1498 r. został on również starostą generalnym wielkopolskim. Ambroży Pampowski, jako jeden z najbliższych współpracowników władcy, uczestniczył we wszystkich kolejnych sejmach walnych zwoływanych przez Jana Olbrachta.

Drugi awans na wojewodę podjęty przez następcę Kazimierza Jagiellończyka w 1496 r. dotyczył przedstawiciela rodu Tarnowskich, w osobie Jana Feliksa Szrama Tarnowskiego (zm. 1507), który piastował urząd stolnika nadwornego ${ }^{23}$. Po koronacji Jana Olbrachta wszedł on w skład dworu królewskiego. Najpierw służył z pocztem 18-konnym, następnie od końca 1493 r. posiadał poczet liczący 24 konie $^{24}$. Po otrzymaniu godności wojewody lubelskiego uczestniczył w sejmie walnym w Piotrkowie w 1496 r. Później pojawił się dopiero na sejmie piotrkowskim w $1501 \mathrm{r}$. Dwaj mianowani przez Jana Olbrachta wojewodowie, sieradzki i lubelski, w latach 1498-1499 dokonywali regularnie sporych wpłat do skarbca królewskiego z dochodów pochodzących z nakładanych podatków ${ }^{25}$.

Kolejne nominacje nowych wojewodów miały miejsce w ostatnich latach panowania Jana Olbrachta. W 1499 r. wojewodą bełskim został wysoko usytuowany w kręgach dworskich Piotr Myszkowski (zm. 1507). Od marca 1493 r. wchodził on w skład dworu królewskiego z pocztem liczącym 16 koni $^{26}$. W senacie zasiadał od 1496 r. z tytułem kasztelana rozpierskiego, a później w 1498 r. jako kasztelan sądecki. Wojewoda Piotr Myszkowski był obecny podczas dwóch ostatnich sejmów, które odbyły się w czasach następcy Kazimierza Jagiellończyka.

Najbardziej znaczącą zmianą w obsadzie najwyższych świeckich godności senackich stanowiła nominacja na początku 1501 r. wojewody krakowskiego Spytka Jarosławskiego na kasztelana krakowskiego i awans na jego miejsce Piotra Kmity (zm. 1505), który do tego czasu nie posiadał czołowej pozycji w senacie ${ }^{27}$. Przedstawiciel rodu Kmitów był głównym pretendentem popieranym przez króla Jana Olbrachta do objęcia najważniejszych urzędów koronnych. W 1493 r. po śmierci marszałka Królestwa Polskiego Rafała Jarosławskiego został on kandydatem na jego następcę i w tej roli wszedł w skład dworu królewskiego w połowie 1493 r. z pocztem liczących $40 \mathrm{koni}^{28}$. Z tej wielkości orszakiem Piotr Kmita sprawował następnie urząd marszałka koronnego, na który oficjalnie otrzymał nominację dopiero 24 marca

21 UrzCentr, nr 1, 62, 274; J. Wiesiołowski, Ambroży Pampowski starosta Jagiellonów, Wrocław 1976, s. 7 i n.

22 Rk 20, k. 142v, 143; Rk 22, k. 2, 3, 3v, 24, 56.

23 UrzCentr, nr 973; W. Dworzaczek, Leliwici Tarnowscy: z dziejów możnowładztwa małopolskiego XIV-XV, Warszawa 1971, s. 208-209, 212, 264, 267-268, 271, 275, 277, 294-295.

24 Rw 2, k. 3.

25 AGAD, Zbiór Dokumentów Papierowych, sygn. 3674, k. 4, 4v, 5.

26 Rw 2, k. 42; A. Kamiński, Myszkowski Piotr, w: PSB, t. 22, Wrocław-Warszawa-Kraków-Gdańsk 1977, s. 379382.

27 F. Papée, Jan Olbracht, dz. cyt., s. 33, 42; R. Trawka, Kmitowie. Studium kariery politycznej i społecznej w Polsce późnośredniowiecznej, Kraków 2005, s. 10 i n.

28 Rw 2, k. 35. Por. R. Trawka, Kmitowie, dz. cyt., s. 225. 
1494 r. ${ }^{29}$ Po uzyskaniu marszałkowstwa Piotr Kmita wszedł w skład senatu, w którym, wraz z urzędnikami koronnymi nieposiadającymi innych godności senatorskich, zajmował miejsce po kasztelanach. Pierwszy raz jego nazwisko widniało w statucie piotrkowskim z 1496 r. Dopiero trzy lata później awansował na kasztelaństwo sandomierskie, które objął po podskarbim koronnym Piotrze Kurozwęckim. Nominacja na wojewodę krakowskiego w 1501 r. stanowiła uwieńczenie jego kariery urzędniczej i przyniosła wpływową pozycję w izbie wyższej sejmu koronnego.

Do liczniejszych zmian wpływających na kształt senatu w latach 1492-1501 doszło przy obsadzie godności kasztelańskich. Trzykrotnie nastąpiły one na kasztelaństwie sandomierskim. W 1494 r. objął je piastujący urząd podskarbiego koronnego Piotr Kurozwęcki (zm. 1499), który, nie posiadając wcześniej tytułu kasztelańskiego, ustępował dostojnikom pełniącym urzędy kasztelanów większych pierwszeństwa w senacie w latach 1492-1493 ${ }^{30}$. Jan Olbracht po śmierci marszałka Rafała Jarosławskiego pod koniec 1492 r. zwlekał z oddaniem tej godności w ręce podskarbiego koronnego z powodu nadmiernej reprezentacji rodu Kurozwęckich w senacie. W jego składzie za panowania następcy Kazimierza Jagiellończyka znajdowali się, będący braćmi, wojewoda lubelski, a następnie sandomierski, Dobiesław, kasztelan sieradzki Mikołaj oraz kanclerz koronny Krzesław, a także podskarbi Piotr Kurozwęccy. Dzięki awansowi na kasztelaństwo sandomierskie Piotr Kurozwęcki zajął drugie po Janie z Ostroroga miejsce pośród kasztelanów uczestniczących w sejmach w 1496 i 1498 r. W 1499 r. kasztelaństwo sandomierskie, jak już wyżej wspomniano, otrzymał marszałek koronny Piotr Kmita. Po jego awansie na wojewodę krakowskiego w 1501 r. godność kasztelana sandomierskiego otrzymał będący członkiem dworu królewskiego Mikołaj Kamieniecki (zm. 1515). Podczas pobytu Jana Olbrachta w Toruniu w 1495 r. w służbie posiadał 15-konny poczet ${ }^{31}$. Z tytułem starosty krakowskiego i sądeckiego był on wymieniany wraz dostojnikami na listach świadków w dokumentach z obrad sejmu w Krakowie w 1499 r.

Niemniej ważne było kasztelaństwo gnieźnieńskie, które Jan Olbracht powierzył w $1496 \mathrm{r}$. marszałkowi nadwornemu Rafałowi Leszczyńskiemu (zm. 1501) ${ }^{32}$. Na liście senatorów znalazł się on podczas sejmu w 1493 r. w zastępstwie marszałka koronnego w związku z wakowaniem urzędu po śmierci Rafała Jarosławskiego. Poza nominacją na kasztelana gnieźnieńskiego Rafał Leszczyński nie doczekał się awansu na wyższą godność senatorską. Do 1501 r. pełnił urząd marszałka nadwornego. Posiadał on mniej liczny poczet niż inni dostojnicy nadworni, który liczył od 16 do $20 \mathrm{koni}^{33}$. W tym czasie obok wykonywana obowiązków związanych z kierowaniem dworem regularnie przekazywał duże kwoty pieniężne podskarbiemu nadwornemu ${ }^{34}$. Jesienią 1496 r. Rafał Leszczyński z 30-konnym pocztem stał na czele delegacji towarzyszącej siostrze królewskiej Barbarze Jagiellonce na jej ślub

\footnotetext{
29 UrzCentr, nr 404; R. Trawka, Kmitowie, dz. cyt., s. 226, 227.

30 UrzCentr, nr 740; F. Kiryk, Kurozwęcki Piotr, w: PSB, t. 16, Wrocław-Warszawa-Kraków-Gdańsk 1971, s. $274-$ -275; B. Nowak, Ród Porajów, dz. cyt., s. 258-262.

31 K. Niemczyk, Kamienieccy herbu Pilawa. Z dziejów kariery i awansu szlachty polskiej do 1535/1536 roku, Katowice 2016, s. 50-52, 133-217; Z. Spieralski, Kamieniecki Mikołaj, w: PSB, t. 11, Wrocław-Warszawa-Kraków 1964-1965, s. 517-520.

32 UrzCentr, nr 444; A. Gąsiorowski, Leszczyński Rafał, w: PSB, t. 17, Wrocław-Warszawa-Kraków-Gdańsk 1972, s. $129-130$.

33 Rw 2, k. 21.

34 AGAD, Zbiór Dokumentów Papierowych, sygn. 3674, k. 9.
} 
z księciem saskim Jerzym Wettynem. W skład delegacji weszli także będący kasztelanami senatorami Piotr Myszkowski z pocztem 24-konnym oraz Mikołaj Gardzina Lubrański z pocztem 12-konnym ${ }^{35}$. Nazwisko marszałka Rafała Leszczyńskiego figurowało następnie w dokumentach sporządzonych podczas obrad sejmu w 1499 r. Dwa lata później był nieobecny na sejmie walnym w Piotrkowie. W sprawowaniu urzędu marszałka dworu zastąpił go wówczas Andrzej Kościelecki (zm. 1515) ${ }^{36}$.

Na liście dostojników, którzy uczestniczyli w obradach sejmu w 1501 r. z tytułem kasztelana gnieźnieńskiego pojawił się piastujący od 1494 r. godność kasztelana lądzkiego Mikołaj Gardzina Lubrański (zm. 1518). Był on bratem biskupa Jana Lubrańskiego. Wcześniej piastował on urząd chorążego nadwornego, z którego przez Jana Olbrachta w 1492 r. został przesunięty na rzecz Zawiszy Róży Borzyszowskiego na kasztelaństwo spycimierskie ${ }^{37}$. Wiosną 1494 r. dołączył on do grona dworzan, do którego należeli pełniący funkcje sekretarzy królewskich jego starsi bracia Jan i Bernard Lubrańscy. Podobnie jak oni posiadał on w służbie poczet liczący 12 koni $^{38}$. Mikołaj Gardzina Lubrański został odnotowany na liście kasztelanów obecnych na sejmie piotrkowskim w 1496 r., a następnie w wąskim gronie dostojników przybyłych na sejm walny w 1501 r. Kasztelaństwo gnieźnieńskie dzierżył on krótko, bowiem jeszcze w tym samym roku został wojewodą kaliskim.

Po nominacji Lubrańskiego na kasztelana gnieźnieńskiego Jan Olbracht nadał godność kasztelana lądzkiego dla Jana Polaka Karnkowskiego (zm. 1503). Doczekał się on tego awansu w uznaniu za sprawowanie funkcji hetmana wojsk zaciężnych, która stawiała go w rzędzie wysokich dostojników królewskich ${ }^{39}$. Podobnie do urzędników dworu posiadał on w służbie poczet, który liczył 24 konie, zaś w wyprawie mołdawskiej w 1497 r. brał udział z pocztem 40-konnym ${ }^{40}$. Na sejmie w 1501 r. został wymieniony w jednym szeregu z kasztelanem lwowskim Stanisławem Chodeckim, który pełnił funkcję hetmana ziem ruskich. Następnie awansował na urząd kasztelana gnieźnieńskiego.

Stanisław Chodecki (zm. 1529) godność kasztelana lwowskiego otrzymał w 1495 r. Uczestniczył w trzech sejmach walnych zwołanych przez Jana Olbrachta, w latach 1496, 1499 i $1501^{41}$. Imię Stanisława, w przeciwieństwie do jego braci: Jana, Piotra oraz Rafała i Ottona, nie widniało na listach dworzan. Zaliczał się on do urzędników królewskich posiadających kompetencje do prowadzenia osobnych rejestrów wydatków z kwot, które dostawał na pełnienie swych funkcji ${ }^{42}$. Stanisław Chodecki w 1505 r. został następcą Piotra Kmity na urzędzie marszałka koronnego.

35 Rw 2, k. 21, 42, 84.

36 VC, t. 1, s. 102.

37 UrzCentr, nr 2; J. Bieniak, Lubrański Mikołaj, w: PSB, t. 18, Wrocław-Warszawa-Kraków-Gdańsk 1973, s. 84-85 .

38 Rw 2, k. 91v.

39 A. Bołdyrew, Piechota zaciężna w Polsce w pierwszej połowie XVI wieku, Warszawa 2011, s. 41, 301-302;

D. Quirini-Popławska, Karnkowski Jan, w: PSB, t. 12, Wrocław-Warszawa-Kraków 1966-1967, s. 73-74.

$40 \quad$ Rk 338, k. 36; Rw 2, k. 10.

41 UrzCentr, nr 405; W. Pociecha, Chodecki Stanisław, w: PSB, t. 3, Kraków 1937, s. 352-354.

42 W rachunkach królewskich Jana Olbrachta zachowała się jedna niedatowana karta rejestru sporządzonego przez Stanisława Chodeckiego. Rw 3, k. 20. W rejestrze dworzan służących na Rusi z 1500 r. odnotowano, że otrzymał on 4000 florenów. Rw 4, k. 130v. Zdarzało się, że Stanisław Chodecki, podobnie jak hetman Jan Trnka i podskarbi koronny Piotr z Kurozwęk, osobiście zajmował się sporządzaniem popisów dworzan. Rk 24, k. 12v. 
W rozdaniu godności senackich przez Jana Olbrachta w 1497 r. pierwszą nominację królewską na urząd kasztelana płockiego po przyłączeniu tej ziemi do Korony w 1495 r. otrzymał przedstawiciel szlachty mazowieckiej Zawisza Dłużniewski (zm. 1504), który wcześniej obejmował kasztelanię wiską ${ }^{43}$. W $1496 \mathrm{r}$. został on przyjęty do służby na polskim dworze z 12-konnym pocztem ${ }^{44}$. Dłużniewski został wymieniony na liście świadków statutu piotrkowskiego z 1496 r. oraz w dokumentach układów przyjętych na sejmie w Krakowie w 1499 r.

W pełniejszym wykazie konsyliarzy królewskich obecnych na sejmie w 1496 r. znajdującym się w statucie piotrkowskim z tytułem kasztelanów, obok wymienionych wyżej Piotra z Kurozwęk, Rafała Leszczyńskiego, Piotra Myszkowskiego i Mikołaja Gardziny Lubrańskiego, pojawiło się kilku dworzan awansowanych na godności kasztelańskie przez Jana Olbrachta. Zaliczał się do nich kasztelan wiślicki Mikołaj Strzeżowski (zm. 1497), który otrzymał nominację na ten urząd w 1494 r. W tym czasie wchodził on w skład dworu królewskiego z pocztem 12-konnym oraz sprawował poselstwa do Turcji w sprawie układów pokojowych ${ }^{45}$. Do grona dworzan należał także mianowany w 1496 r. na kasztelana spycimierskiego Jan Jarand z Brudzewa (zm. 1532), który był synem wojewody sieradzkiego Mikołaja z Brudzewa (zm. 1494) ${ }^{46}$.

Pojawił się tam również Jakub Drzewicki (zm. 1497), który awansował na kasztelana żarnowskiego w 1495 r. po przeniesieniu na kasztelaństwo radomskie jednego z najbardziej wpływowych dworzan, Jana Podlodowskiego ${ }^{47}$. Jakub Drzewicki zawdzięczał nominację swym synom, którzy służyli na dworze królewskim, Maciejowi, Hieronimowi i Janowi, do których pod koniec panowania następcy Kazimierza Jagiellończyka dołączył też Adam Drzewicki ${ }^{48}$. W ostatnich miesiącach przed śmiercią Jana Olbrachta w szeregi dworzan zaliczony został obecny na sejmie w 1496 r. kasztelan rypieński Mikołaj Kretkowski (zm. 1520), który w 1497 r. otrzymał kasztelaństwo brzeskie. Wejście w skład dworu królewskiego ułatwiło mu objęcie urzędu wojewody inowrocławskiego, do którego pretendował ${ }^{49}$.

Jan Olbracht był kontynuatorem długoplanowej polityki nominacyjnej na godności senackie prowadzonej przez króla Kazimierza Jagiellończyka, za panowania którego powstał sejm walny. Wykorzystywał nominacje do wywierania wpływu na kształt senatu poprzez obsadzenie izby wyższej najbliższymi współpracownikami królewskimi. Godności biskupów, wojewodów i kasztelanów otrzymywali przede wszystkim członkowie dworu związani z kancelarią koronną, urzędnicy i sekretarze królewscy. Polski dwór za panowania Jana

\footnotetext{
43 J. Piętka, Mazowiecka elita feudalna późnego średniowiecza, Warszawa 1975, s. 58-59; Stownik historyczno-geograficzny województwa płockiego w średniowieczu, oprac. A. Borkiewicz-Celińska, z. 1-2, Wrocław 19801981, s. 132-133.

44 Rw 2, k. 97.

45 Rw 2, k. 84; M. Wilamowski, Strzeżowski Mikołaj, w: PSB, t. 45, Warszawa-Kraków 2008, s. 77-79.

46 W. Pociecha, Brudzewski Jan Jarand, w: PSB, t. 3, Kraków 1937, s. 5-6; S. Szybkowski, Król Jan Olbracht wobec możnowładztwa ziem środkowopolskich, w: Jagiellonowie i ich świat. Dynastia królewska w drugiej połowie XV i w XVI wieku, red. B. Czwojdrak, J. Sperka, P. Węcowski, Kraków 2016, s. 313, 314, 316, 322-323.

47 Rw 2, k. 69; I. Kaniewska, Podlodowski Jan, w: PSB, t. 17, Wrocław-Warszawa-Kraków-Gdańsk 1972, s. 129130.

48 H. Rybus, Prymas Maciej Drzewiecki: zarys biografii (1467-1535), Warszawa 1964, s. $28,29$.

49 D. Quirini-Popławska, Kretkowski Mikołaj, w: PSB, t. 15, Wrocław-Warszawa-Kraków 1970, s. 284; T. Sławiński, Kretkowscy i ich dzieje od połowy XIV wieku, Warszawa 2011, s. 89-102.
} 
Olbrachta stał się szkołą przyszłych senatorów, którzy decydowali o państwie w czasach kolejnych władców z dynastii jagiellońskiej.

\section{Bibliografia}

\section{Źródla rękopiśmienne}

Archiwum Główne Akt Dawnych w Warszawie, Archiwum Skarbu Koronnego, Oddział 1, Rachunki Królewskie, sygn. 20, 22, 24, 26, 28, 338. Oddział 86, Rachunki z przychodów i wydatków na potrzeby wojska, sygn. 2, 3, 4; Metryka Koronna, sygn. MK 15, 16, 17, 19; Zbiór Dokumentów Pergaminowych, sygn. 152.

\section{Źródla drukowane}

Volumina Constititionum, t. 1: 1493-1526, oprac. S. Grodziski, I. Dwornicka, W. Uruszczak, Warszawa 1996.

\section{Opracowania}

Baczkowski K., Przerębski Wincenty, w: Polski Słownik Biograficzny (dalej: PSB), t. 29, Wrocław-Warszawa-Kraków-Gdańsk-Łódź 1986, s. 4-7.

Bieniak J., Lubrański Mikołaj, w: PSB, t. 18, Wrocław-Warszawa-Kraków-Gdańsk 1973, s. 84-85.

Bołdyrew A., Piechota zaciężna w Polsce w pierwszej połowie XVI wieku, Warszawa 2011.

Brzozowski J., Zygmunt I a senat koronny w latach 1506-1535, „Białostockie Teki Historyczne", 9/2011, s. 11-39.

Chorążyczewski W., Przemiany organizacyjne polskiej kancelarii królewskiej u progu czasów nowożytnych, Toruń 2007.

Dworzaczek W., Leliwici Tarnowscy: z dziejów możnowładztwa małopolskiego XIV-XV, Warszawa 1971.

Gąsiorowski A., Leszczyński Rafał, w: PSB, t. 17, Wrocław-Warszawa-Kraków-Gdańsk 1972, s. 129-130.

Hajdukiewicz L., Lubrański Jan, w: PSB, t. 18, Wrocław-Warszawa-Kraków-Gdańsk 1973, s. 81-84.

Kamiński A., Myszkowski Piotr, w: PSB, t. 22, Wrocław-Warszawa-Kraków-Gdańsk 1977, s. 379-382.

Kaniewska I., Podlodowski Jan, w: PSB, t. 17, Wrocław-Warszawa-Kraków-Gdańsk 1972, s. $129-130$.

Kiryk F., Kurozwęcki Piotr, w: PSB, t. 16, Wrocław-Warszawa-Kraków-Gdańsk 1971, s. 274-275.

Kujawski W., Krzesław z Kurozwęk, wielki kanclerz koronny i biskup włocławski, „Studia Włocławskie", 7/2004, s. 340-354.

Kutrzeba S., Sktad Sejmu Polskiego 1493-1793, „Przegląd Historyczny”, 2/1906, z. 1, s. 43-76. Niemczyk K., Kamienieccy herbu Pilawa. Z dziejów kariery i awansu szlachty polskiej do 1535/1536 roku, Katowice 2016.

Nowak B., Ród Porajów w Małopolsce w średniowieczu, Kraków 2009.

Papée F., Boryszewski Andrzej Róża, w: PSB, t. 2, Kraków 1936, s. 359-360.

Papée F., Jan Olbracht, Kraków 2006 (wyd. 1, 1936). 
Piętka J., Mazowiecka elita feudalna późnego średniowiecza, Warszawa 1975.

Pociecha W., Brudzewski Jan Jarand, w: PSB, t. 3, Kraków 1937, s. 5-6.

Pociecha W., Chodecki Stanisław, w: PSB, t. 3, Kraków 1937, s. 352-354.

Quirini-Popławska D., Karnkowski Jan, w: PSB, t. 12, Wrocław-Warszawa-Kraków 1966-1967, s. 73-74.

Quirini-Popławska D., Kretkowski Mikołaj, w: PSB, t. 15, Wrocław-Warszawa-Kraków 1970, s. 284.

Rybus H., Prymas Maciej Drzewiecki: zarys biografii (1467-1535), Warszawa 1964.

Sławiński T., Kretkowscy i ich dzieje od połowy XIV wieku, Warszawa 2011.

Słownik historyczno-geograficzny województwa płockiego w średniowieczu, oprac. A. Borkiewicz-Celińska, z. 1-2, Wrocław 1980-1981.

Spieralski Z., Kamieniecki Mikołaj, w: PSB, t. 11, Wrocław-Warszawa-Kraków 1964-1965, s. $517-520$.

Strzelecka A., Krajewski (Krajowski) Mikołaj, zwany Primus (zm. 1498), w: PSB, t. 15, Wrocław-Warszawa-Kraków 1970, s. 113-114.

Szybkowski S., Król Jan Olbracht wobec możnowładztwa ziem środkowopolskich, w: Jagiellonowie i ich świat. Dynastia królewska w drugiej połowie XV i w XVI wieku, red. B. Czwojdrak, J. Sperka, P. Węcowski, Kraków 2016, s. 303-330.

Trawka R., Kmitowie. Studium kariery politycznej i społecznej w Polsce późnośredniowiecznej, Kraków 2005.

Uruszczak W., Najstarszy sejm walny koronny „dwuizbowy” w Piotrkowie w 1468 roku, w: Narodziny Rzeczypospolitej: studia z dziejów średniowiecza i czasów wczesnonowożytnych, red. W. Bukowski, T. Jurek, t. 2, Kraków 2012, s. 1033-1056.

Uruszczak W., Sejm koronacyjny w 1507 roku w Krakowie, „Studia z Dziejów Państwa i Prawa Polskiego", 7/2002, s. 111-121.

Urzędnicy centralni i nadworni Polski XIV-XVIII wieku. Spisy, oprac. K. Chłapowski i in., red. A. Gąsiorowski, Kórnik 1992.

Wiesiołowski J., Ambroży Pampowski starosta Jagiellonów, Wrocław 1976.

Wilamowski M., Strzeżowski Mikołaj, w: PSB, t. 45, Warszawa-Kraków 2008, s. 77-79. 